Çukurova Üniversitesi Mühendislik Mimarlık Fakültesi Dergisi, 32(2), ss. 207-213, Haziran 2017

Çukurova University Journal of the Faculty of Engineering and Architecture, 32(2), pp. 207-213, June 2017

\title{
Katı Molibden Bileşiklerinin Elektrokimyasal İndirgenmesiyle Molibden Üretimi
}

\author{
Metehan ERDOĞAN ${ }^{* 1}$, Bengisu AKPINAR ${ }^{2}$, İshak KARAKAYA ${ }^{2}$ \\ ${ }^{1}$ Ankara Yıldırım Beyazıt Üniversitesi, Mühendislik Fakültesi, Metalurji ve Malzeme \\ Mühendisliği Bölümü, Ankara \\ ${ }^{2}$ Orta Doğu Teknik Üniversitesi, Mühendislik Fakültesi, Metalurji ve Malzeme Mühendisliği \\ Bölümü, Ankara
}

Geliş tarihi: 09.05.2017 Kabul tarihi: 31.05 .2017

$\ddot{\mathbf{O} z}$

İletken bir telin ucuna tutturulmak suretiyle hücrenin katodunu oluşturan, molibden bileşikleri; $\mathrm{CaMoO}_{4}$ ve $\mathrm{MoS}_{2}$ 'nin elektrokimyasal yöntemlerle indirgenmesi incelenmiştir. Elektrolit olarak, erimiş haldeki $\mathrm{CaCl}_{2}-\mathrm{NaCl}$ tuz çözeltileri kullanılmıştır. İndirgenen örneklerin içeriği ve morfolojisi X-1şınları kırınımı (XRD) ve taramalı elektron mikroskobu (SEM) analizleri aracılığıyla belirlenmiştir. Yapılan incelemeler $\mathrm{CaMoO}_{4}$ 'ten elektrokimyasal indirgeme yöntemiyle kayıp vermeksizin Mo üretmenin mümkün olmadığını göstermiştir. Söz konusu bileşik ötektik $\mathrm{CaCl}_{2}-\mathrm{NaCl}$ çözeltisi içerisinde $750^{\circ} \mathrm{C}$ 'de yaklaşık $\% 1,9$ civarında çözünürlüğe sahiptir. Çözünürlüğün nispeten önemsiz olduğu $600^{\circ} \mathrm{C}$ 'de ise Mo oluşumu gözlemlenmemiştir. Molibdenin doğadaki en önemli minerali olan $\mathrm{MoS}_{2}$ 'den elektrokimyasal indirgeme yöntemiyle Mo üretimi ise $750{ }^{\circ} \mathrm{C}$ 'de başarıyla gerçekleştirilmiştir. İndirgenen numunedeki kalsiyum bileşiklerinin seyreltik asit çözeltisinde çözündürülmesi ile saf Mo tozu elde edilmiştir.

Anahtar Kelimeler: Elektrokimyasal indirgeme, Elektrodeoksidasyon, $\mathrm{Mo}, \mathrm{CaMoO}_{4}, \mathrm{MoS}_{2}$

\section{Molybdenum Production by the Electrochemical Reduction of Solid Molybdenum Compounds}

\begin{abstract}
The electrochemical reduction of molybdenum compounds; $\mathrm{CaMoO}_{4}$ and $\mathrm{MoS}_{2}$, which form the cathode of the cell by being attached to a current collector, was investigated. Molten $\mathrm{CaCl}_{2}-\mathrm{NaCl}$ salt solutions were used as the electrolyte. The compositions and morphologies of the reduced samples were determined by X-ray diffraction (XRD) and scanning electron microscopy (SEM) analyses. The examinations showed that it is not possible to produce Mo without loss by the electrochemical reduction of $\mathrm{CaMoO}_{4}$. The aforementioned compound has around $1.9 \%$ solubility in eutectic $\mathrm{CaCl}_{2}-\mathrm{NaCl}$ salt solution at $750^{\circ} \mathrm{C}$. Formation of Mo was not observed at $600^{\circ} \mathrm{C}$ where the solubility was relatively not important. On the other hand, production of molybdenum from $\mathrm{MoS}_{2}$, which is the most important Mo mineral found in nature, was accomplished successfully. Pure molybdenum powder was obtained by the dissolution of calcium products found in the reduced samples in dilute acid solution.
\end{abstract}

Keywords: Electrochemical reduction, Electrodeoxidation, $\mathrm{Mo}, \mathrm{CaMoO}_{4}, \mathrm{MoS}_{2}$

*Sorumlu yazar (Corresponding author): Metehan ERDOĞAN, metehanerdogan@ybu.edu.tr 


\section{GíRiș}

Atom numarası 42, atom ağırlı̆̆ $95,95 \mathrm{~g}$ ve yoğunluğu $10,2 \mathrm{~g} / \mathrm{cm}^{3}$ olan molibden, periyodik tabloda bakırla tungsten arasında bulunmaktadır. Krom ve tungsten ile benzer kimyasal özellikler gösteren molibden; yüksek erime $\left(2610^{\circ} \mathrm{C}\right)$ ve kaynama sıcaklıkları $\left(5560^{\circ} \mathrm{C}\right)$, yüksek $1 \mathrm{~S} 1$ dayanımı, yüksek 1sı iletkenliği ve düşük termal genleşme gibi üstün özelliklere sahiptir [1]. Yaklaşık 10 kadar molibden ihtiva eden mineral bilinmesine rağmen, ekonomik değere sahip tek mineral molibdenittir $\left(\mathrm{MoS}_{2}\right)$. Diğer bazı mineraller vulfenit $\left(\mathrm{PbMoO}_{4}\right)$ ve povellittir $\left(\mathrm{CaMoO}_{4}\right)[1]$.

Saf molibden tozu üretimi için dünya çapında uygulanan proses molibden oksidin hidrojen ile indirgenme prosesidir. Fakat bu yöntemde molibden oksit üretimine kadar çok sayıda adım bulunması ve molibdenin oksidin indirgenmesi için yüksek sıcaklıklar ve hidrojen kullanılması prosesi zorlaştırmakta ve maliyetini arttırmaktadır.

1997 yllinda Fray, Farthing ve Chen, FFC Cambridge prosesi [2] olarak da bilinen yeni bir elektrodeoksidasyon prosesi geliştirmişlerdir. FFC Cambridge prosesi, erimiş tuz çözeltileri oksitten metal veya alaşım elde etmeyi sağlayan bir elektrometalurji prosesidir. Yöntem, toz haldeki metal bileşiklerin sinterlenerek peletlenmesini ve takiben hazırlanan bu peletin katı halde indirgenmesini içermektedir. Klasik erimiş tuz elektrolizi ile arasındaki en büyük fark olarak, başlangıç malzemesinin, elektrolit içerisinde çözdürülmemesi gösterilebilir. Söz konusu yöntemle, başta Ti [3] olmak üzere $\mathrm{Cr}$ [4], Si [5], $\mathrm{Cu}$ [6], Al, B, Fe, V, Nb, U, Nd, Zr, Hf, Ce ve Ni [7-10] dahil bir çok metal ve metal ve metal alaşımının üretildiği literatürde duyurulmuştur.

Ancak, tarafimızdan yapılan incelemeler, FFC Cambridge prosesi ile molibden oksitten, kayıp vermeksizin molibden elde etmenin mümkün olamayacağını göstermektedir. Proses için gerekli olan sicaklıklarda $\left(\approx 900^{\circ} \mathrm{C}\right)$ molibden oksit ve kalsiyum klorür, uçucu bir madde olan molibden oksiklorür çıkışıyla sonuçlanan bir reaksiyona girmektedirler.
$2 \mathrm{MoO}_{3}(\mathrm{k})+\mathrm{CaCl}_{2}(\mathrm{~s})=\mathrm{CaMoO}_{4}(\mathrm{k})+\mathrm{MoO}_{2} \mathrm{Cl}_{2}(\mathrm{~g})(1)$

Benzer bir problem tungsten oksitten tungsten metali üretiminde de mevcuttur. Tungsten özelinde, reaksiyonda $\mathrm{WO}_{3}$ yerine $\mathrm{CaWO}_{4}$ kullanılmasıyla ağırlıkça en az \%99 saflıkta tungsten eldesi başarı ile gerçekleşmiştir [11,12]. Yöntem, Kanada, Rusya ve Türkiye olmak üzere 3 farklı ülkede korumaya alınarak patentlenmiştir [13-15].

$\mathrm{Bu}$ çalışmada, benzer bir yöntemle, $\mathrm{CaMoO}_{4}$ 'ten Mo üretiminin yapılabilirliği incelenmiştir. Başlangıç malzemesi olarak kullanılan bir diğer Mo bileşiği ise $\mathrm{MoS}_{2}$ 'dir. Uygun koşullar altında kükürdün tıpkı oksijen gibi katı fazdan uzaklaştırılabileceği düşünülmektedir. Bu bileşiğin indirgenmesiyle Mo üretiminin gerçekleştirilebilmesi, $\mathrm{MoS}_{2}$ doğada bulunan en önemli Mo minerali olduğundan ayrıca önem taşımaktadır.

Ülkemizde de bu önemli elementi üretmek için kullanılabilecek molibden rezervleri bulunmaktadır. 2012 yılında, ilk olarak Özdoğu İnş. ve Tic. A.Ş'nin iştiraki olan Kuzey-Ege Bakır İşletmesi tarafından Balıkesir Havran'da molibden konsantresi üretilmeye başlanmıştır. $\mathrm{Bu}$ bölgede yaklaşık 17,5 milyon ton molibden bakır rezervi tespit edilmiştir. Açık ocak işletmeciliği şeklinde üretim yapılmaktadır. Çıkarılan cevher işlenerek \%46 tenörlü molibden konsantresine dönüştürülmektedir. $\mathrm{Bu}$ rakamın ileriki yıllarda $\% 55$ 'e çıkarılması hedeflenmektedir [16].

Molibden (Mo) ve molibden alaşımları çoğunlukla paslanmaz çelik tüp ve boru şeklindeki aletlerin yapımında, süper 1sitıcılarda, petrol ürünlerinin elde edilmesinde, roket ve füze sistemlerinde yüksek sıcaklığa sahip çıkış gazlarına maruz kalan lüle, lüle bileşenleri ve bazı yapısal parçalarda kullanılmaktadır. Ancak, bu denli geniş ve kritik kullanım alanlarına sahip molibden metalinin yerli üretimi bulunmamaktadır. $\mathrm{Bu}$ projenin amacı, erimiş tuz içerisinde elektrokimyasal indirgeme yöntemiyle, $\mathrm{MoS}_{2}$ ve $\mathrm{CaMoO}_{4}$ hammaddelerinden laboratuvar ölçeğinde Mo tozu üretmektir. 


\section{MATERYAL VE METOT}

Deneylerde $2 \mathrm{~g} \mathrm{CaMoO}_{4}$ veya $\mathrm{MoS}_{2}$ tozu 2 ton yük altında peletlenmiş ve sinterlenmeden kullanılmıştır. Tozlara ait SEM görüntüleri Şekil 1'de verilmektedir.

(a)

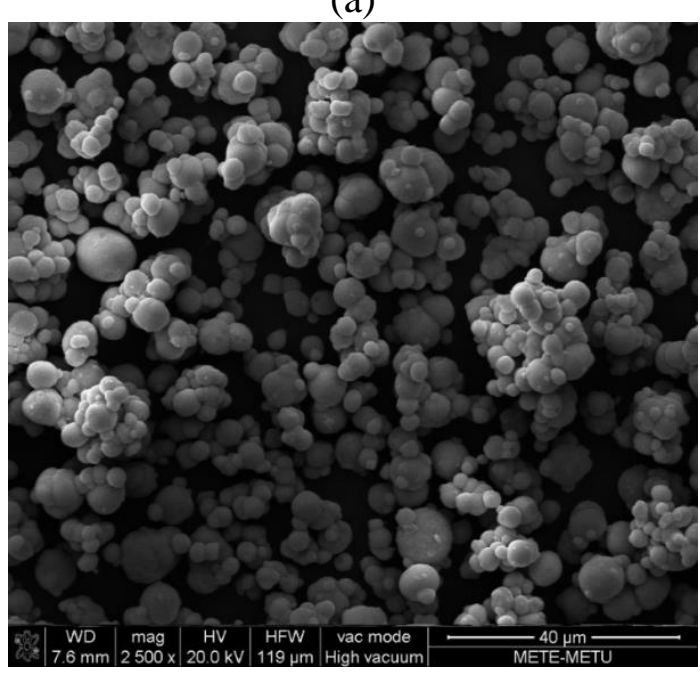

(b)

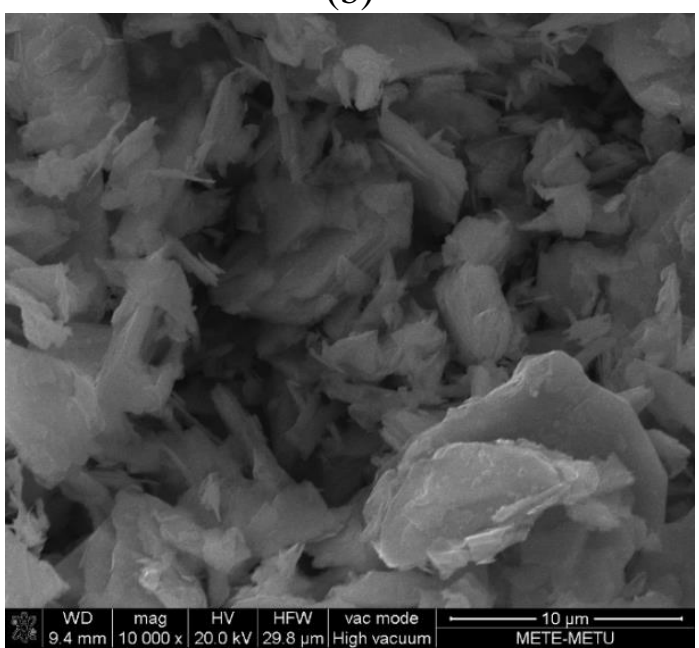

Şekil 1. (a) $\mathrm{CaMoO}_{4}$ (b) $\mathrm{MoS}_{2}$ tozunun SEM görüntüleri

Kuvars tüp içine ötektik kompozisyonda $100 \mathrm{~g}$ $\mathrm{CaCl}_{2}-\mathrm{NaCl}$ içeren alumina kroze yerleştirilmiştir. Paslanmaz çelik bir kaşık peletle beraber katot, grafit bir çubuk ise anot olarak kullanılmıştır.
Hedeflenen sıcaklığa ulaşıldığında elektrotlar erimiş tuz içerisine daldırılmış ve $2,8 \mathrm{~V}$ sabit potansiyel farkı altında deneyler başlatılmıştır. Bütün 1sıtma ve elektroliz işlemi, indirgeyici bir ortam oluşturmak ve gaz fazındaki reaksiyon ürünlerini dışarı taşımak için devamlı argon gazı akışı altında (200 cc/dk) gerçekleştirilmiştir. Deney düzeneğinin şematik bir görüntüsü Şekil 2'de verilmektedir.

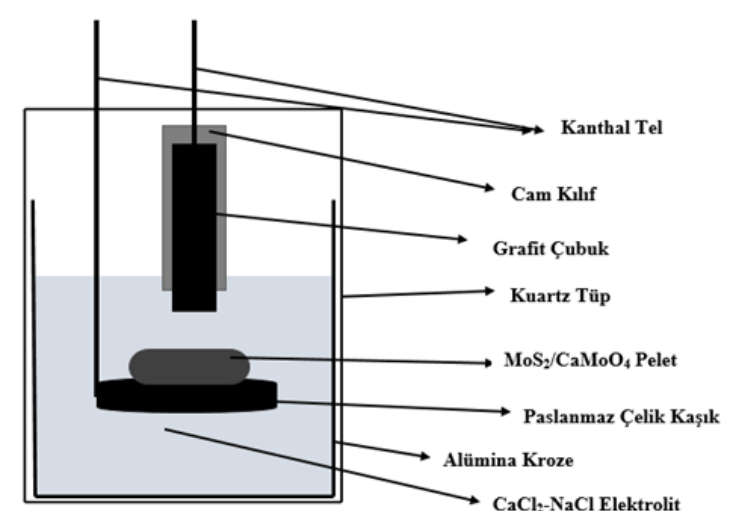

Şekil 2. Deney düzeneğinin şematik görüntüsü

Deneyin tamamlanmasının ardından elektrotlar erimiş tuzdan çıkarılmış ve argon gazı akışı altında soğumaya bırakılmıştır. Katottan alınan ürünler saf su ile yıkanıp süzülerek toz örnek alınmıştır. Bazı deneylerden sonra alınan örnekler, reaksiyon yan ürünlerinden kurtulmak için $0,2 \mathrm{M} \mathrm{HCl}$ çözeltisiyle bir temizleme işlemine tabi tutulmuştur. Ürünlerin ve hammaddelerin karakterizasyonunda XRD (Rigaku D/max-2200), XRF (Fischerscope X-Ray XDV-SDD) ve SEM (FEI Nova Nano430) cihazları kullanılmıştır.

\section{BULGULAR VE DEĞERLENDİRME}

\section{1. $\mathrm{CaMoO}_{4}{ }^{\prime}$ ün Elektrokimyasal İndirgenmesi}

FFC Cambridge prosesiyle $\mathrm{MoO}_{3}$ 'ten kayı vermeksizin Mo üretmek mümkün değildir.

Elektrokimyasal indirgeme için gerekli sicaklıklarda $\mathrm{MoO}_{3}$ ve $\mathrm{CaCl}_{2}$ reaksiyona girerek $\mathrm{CaMoO}_{4}$ ve uçucu bir bileşik olan $\mathrm{MoO}_{2} \mathrm{Cl}_{2}$ oluşturmaktadır. FACT thermodynamics programıla, laboratuvar deneylerinde kullanılan 
değerler olan 2 gram $\mathrm{MoO}_{3}$ ve 100 gram $\mathrm{CaCl}_{2}$ için $900^{\circ} \mathrm{C}$ 'de yapılan denge hesabı Şekil 3 'de verilmiştir. Buradan görülebileceği gibi başlangıçta bulunan Mo'nun bir kısmı, $\mathrm{MoO}_{2} \mathrm{Cl}_{2}$ olarak kaybedilmiștir. Daha düşük sıcaklıklarda $\left(600^{\circ} \mathrm{C}\right.$ gibi) yapılan denge hesaplarında da durum farklı değildir. $\mathrm{Bu}$ reaksiyonun önüne geçilmesi için $\mathrm{CaMoO}_{4}$ başlangıç malzemesi olarak kullanılması ve $\mathrm{MoO}_{3}$ yerine bu bileșiğin elektrolizi sonucu molibden eldesi hedeflenmiştir.

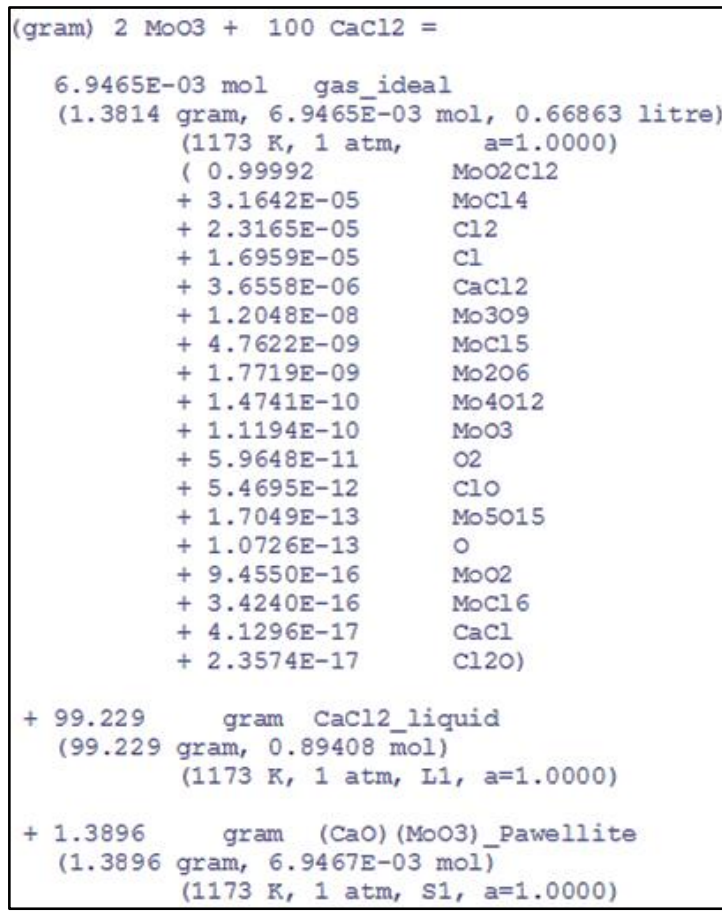

Şekil 3. FACT Thermodynamics programıla belirtilen koşullarda yapılan denge hesab1

$\mathrm{Bu}$ bilgiler 1şığında ilk deney $600^{\circ} \mathrm{C}$ 'de ötektik $\mathrm{CaCl}_{2}-\mathrm{NaCl}$ tuz çözeltisi içerisinde $2,8 \mathrm{~V}$ sabit potansiyel farkı altında gerçekleştirilmiştir. Uygulanan $2,8 \mathrm{~V}$ potansiyel fark $1, \mathrm{CaCl}_{2}(3,3 \mathrm{~V})$ ve $\mathrm{NaCl}(3,4 \mathrm{~V})$ tuzlarının elektrolizi için bu sıcaklıkta gereken potansiyelin altındadır. Çıkan numuneden alınan XRD sonuçları Sekil 4'te verilmektedir. Şekil 4'ten görülebileceği gibi, üretilen tozda molibden fazına rastlanmamıştır. Sistemde molibden görülmemesinin sebebi olarak, hazırlanan peletin deney sıcaklığına çıkıldığı esnada sinterlenmiş olabileceği düşünülmüştür. Pelet sinterlendiği zaman, yüzeyde indirgenme tamamlandiktan sonra, $\mathrm{CaMoO}_{4}$ ile tuz temas1 zorlaşmakta ve indirgenme işlemi çok yavaşlamaktadır.

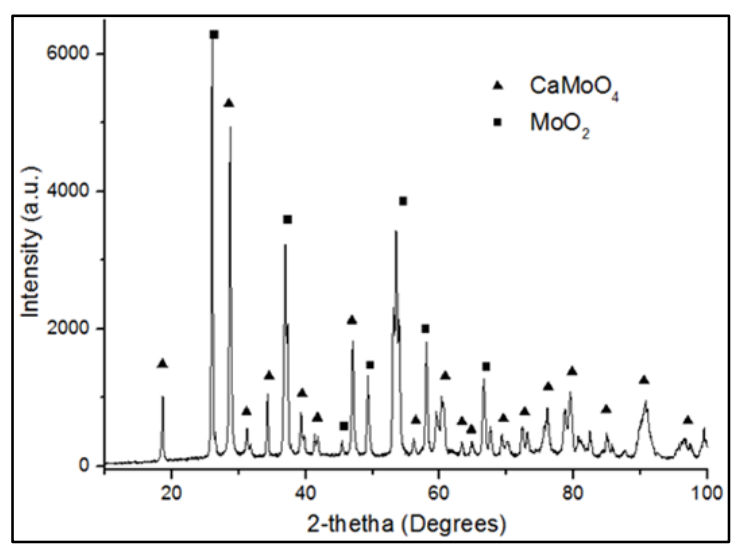

Şekil 4. $\mathrm{CaMoO}_{4}$ başlangıç tozu ile $600^{\circ} \mathrm{C}^{\prime} \mathrm{de}$ yapilan deneyden elde edilen numunenin XRD analizi sonucu

Yapılan çalışmalar elektrokimyasal indirgeme prosesi için hız belirleyici adım olarak oksijenin katı fazdaki difüzyonunu göstermektedir [4]. Takiben yapılan deneyde katı fazda difüzyonu hızlandırmak için sıcaklık $750^{\circ} \mathrm{C}$ 'ye çıkarılmıştır. Yine reaksiyonu hızlandırmak için, artan sıcaklık sayesinde mol olarak $\% 70 \mathrm{CaCl}_{2}-\% 30 \mathrm{NaCl}$ tuz karışımı kullanılabilmiş ve böylece oksijen çözünürlüğü daha fazla olan $\mathrm{CaCl}_{2}$ tuzunun miktarı artırılmıştır. Deney sonucunda kaşıktan toplanan tozun XRD sonucu Şekil 5'te verilmektedir. Analiz sonucunda sistemde bir önceki deneyin aksine indirgenme görülmüş fakat Mo'nun büyük kısmının anottan tuza karışan grafit tozlarıyla, yüksek sicaklığın da etkisiyle $\mathrm{Mo}_{2} \mathrm{C}$ oluşturduğu anlaşılmıştır.

$\mathrm{CaMoO}_{4}$ şeklinde sisteme koyulan Mo'nun $\%$ 50'sinden daha azı paslanmaz çelik kaşık üzerinden toplanabilmiştir. $\mathrm{Bu}$ durum $\mathrm{CaMoO}_{4}$ 'ün söz konusu tuz çözeltisi içerisinde çözünürlüğü olabileceği ihtimalini düşündürmüştür. $\mathrm{CaMoO}_{4}$ 'ün $\mathrm{CaCl}_{2}-\mathrm{NaCl}$ tuz karışımı içindeki çözünürlüğü için literatürde herhangi bir bilgiye rastlanmamıştır. Devam eden deneylerde başlangıç 
tozunun, kullanılan tuz içindeki çözünürlüğü çalışılarak, prosese yön verilmesi ve literatüre bu konuda katkıda bulunulması hedeflenmiştir.

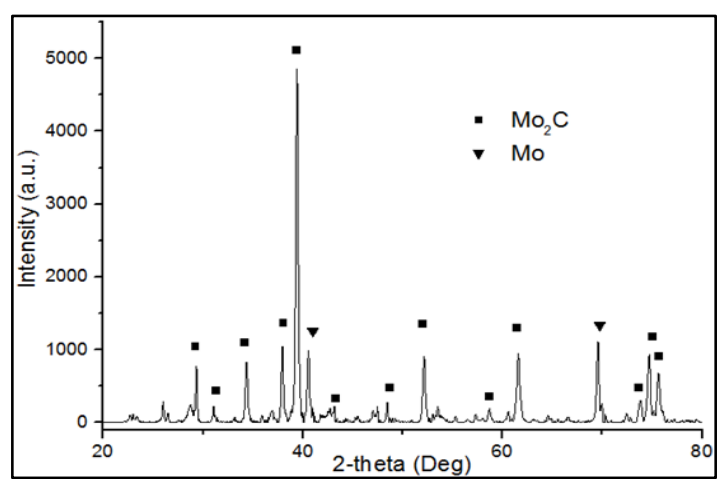

Şekil 5. $\mathrm{CaMoO}_{4}$ başlangıç tozu ile $750{ }^{\circ} \mathrm{C}^{\prime} \mathrm{de}$ yapilan deneyden elde edilen numunenin XRD analizi sonucu. Tanımlanmayan düşük yükseklikteki pikler tuz kalıntılarına aittir

Çözünürlük belirleme çalışması için $2 \mathrm{~g} \mathrm{CaMoO}_{4}$ pelet, Kanthal telin ucuna tutturulmuş tungsten tele takılarak $750^{\circ} \mathrm{C}$ 'deki $\% 70 \mathrm{CaCl}_{2}-\% 30 \mathrm{NaCl}$ tuz karışımına daldırılmış ve 12 saat bekletilmiştir. Takiben tuzdan numune alınmış ve alınan numune su içerisinde bekletilerek tuzu çözülmüş ve katı toz elde edilmiştir. Alınan tuz miktarı 5,26 g ve süzme sonunda elde edilen toz miktarı 0,21 g olarak tartılmıştır. Elde edilen tozun kompozisyonunu belirlemek için yapılan XRF analizi sonucu Çizelge 1'de verilmektedir.

Çizelge 1. XRF analizlerinin ortalamaları alınarak bulunan element yüzdeleri

\begin{tabular}{|c|c|}
\hline Element & $\%$ \\
\hline Mo & 67,3 \\
\hline $\mathrm{Ca}$ & 32,7 \\
\hline
\end{tabular}

XRF analizi yapılan cihaz ile hafif bir element olan oksijen yüzdesi güvenilir olarak tespit edilememektedir. Bu sebeple Tablo 1'de oksijen çıkarılarak hesaplanan Mo ve $\mathrm{Ca}$ değerleri verilmiştir. Elde edilen tozun tamamı $\mathrm{CaMoO}_{4}$ olarak kabul edilse, $\mathrm{Ca} / \mathrm{Mo}$ ağırlık oranı 0,42 olmalidir. Elde edilen numunede ise bu oran 0,49'dur. Bu durum tuz içerisinde $\mathrm{CaMoO}_{4}$ dışında bir $\mathrm{Ca}$ bileşiğinin de bulunduğunu göstermektedir.
$\mathrm{Bu}$ bileşiğin tuz kurutulması sırasında oluşma ihtimali bulunan $\mathrm{CaO}$ olduğu düşünülmüştür. Tozdan alınan XRD deseni (Şekil 6) bu durumu doğrulamıştır. Numuneyi donmuş tuzdan arındırma işlemi sırasında, $\mathrm{CaO} \quad \mathrm{H}_{2} \mathrm{O}$ ile reaksiyona girerek $\mathrm{Ca}(\mathrm{OH})_{2}$ oluşmuştur.

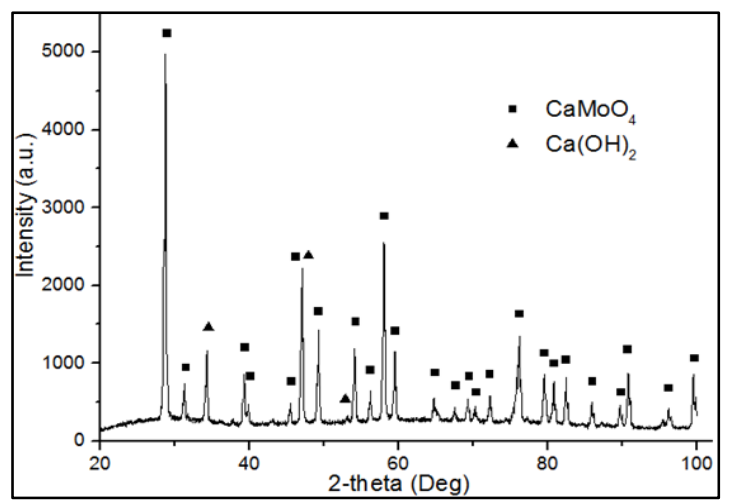

Şekil 6. Donmuş tuzdan arındırılan tozun XRD deseni

Tartılan 0,21 g tuzun $\mathrm{CaMoO}_{4}$ ve $\mathrm{Ca}(\mathrm{OH})_{2}$ 'den oluştuğu ve Tablo 1'deki XRF analizi bilgileriyle tozun içerisindeki $\mathrm{CaMoO}_{4}$ miktarı $0,10 \mathrm{~g}$ olarak bulunmuştur. $\mathrm{Bu} \mathrm{CaMoO}_{4}$ miktarının 5,26 g tuz içerisinde bulunduğu dikkate alınarak, bahsi geçen tuz içerinde $\mathrm{CaMoO}_{4}$ çözünürlüğü, $\quad 750^{\circ} \mathrm{C}^{\prime} \mathrm{de}$ yaklaşık \%1,9 olarak hesaplanmıştır.

Deneylerde $2 \mathrm{~g} \mathrm{CaMoO}_{4}$ tozu $100 \mathrm{~g}$ tuz karışımı içerisine daldırılmaktadır. Bu durumda, $750^{\circ} \mathrm{C}$ 'de 12 saat sonunda $\mathrm{CaMoO}_{4}{ }^{\prime}$ ün neredeyse tamamının çözüleceği görülmektedir. Tarafımızdan yapılan deneyde ise başlangıçtaki Mo'nun yaklaşık yarısı kaşık üzerinden toplanmıştır. Bunun sebebi, elektrotları daldırır daldırmaz elektrik akımının verilmesi ve reaksiyonun başlatılmasıdır. Bir yandan çözünme işlemi devam ederken, bir yandan da elektrokimyasal indirgeme gerçekleşmiştir.

Tuz içerisinde çözünmüş halde bulunan Mo iyonlarının elektrolizle toplanması da mümkündür. Ancak söz konusu sicaklıkta sivi fazdan toplanan Mo katı fazda olacaktır. Bu yolla üretilen metaller genellikle dendritik olup sonraki metalurjik uygulamalar için uygun olmamakta ve kolay oksitlenebilmektedir. 


\section{2. $\operatorname{MoS}_{2}{ }^{\prime}$ nin Elektrokimyasal İndirgenmesi}

2007 yılında gerçekleştirilen bir çalışmaya göre, $\mathrm{MoS}_{2}$ 'den $\mathrm{CaCl}_{2}$ erimiş tuz çözeltisi içinde elektrokimyasal indirgeme yöntemiyle Mo eldesi mümkündür [17]. $\mathrm{Bu}$ yöntemle $300^{\circ} \mathrm{C}^{\prime} \mathrm{de}$ sinterlenerek peletlenen $\mathrm{MoS}_{2}$, erimiş $\mathrm{CaCl}_{2}$ içerisinde elektrokimyasal olarak Mo ve S'ye indirgenmiștir. Oluşan kükürdün çok az bir kısmı grafit anotla reaksiyona girerek, $\mathrm{CS}_{2}$ olarak açığa çıkmıștır. Elektrokimyasal indirgeme işlemi $800-900^{\circ} \mathrm{C}^{\prime}$ lerde, argon ortamında ve $1-20$ saat arasında gerçekleştirilmiştir [17].

Yukarıda bahsi geçen çalışmanın 1şı̆̆ında, elektrokimyasal yöntemle molibden tozu üretimi için çalışılan başka bir başlangıç malzemesi de $\mathrm{MoS}_{2}$ tozudur. İlk deney, $\mathrm{MoS}_{2}$ peletin tungsten tele geçirilmiş halde ötektik tuz karışımına daldırılmasıyla 2,8 V sabit voltaj farkı altında ve $600^{\circ} \mathrm{C}$ 'de yapılmıştır. Alınan numune XRD ile analiz edilmiş ve çok az indirgenme olduğu tespit edilmiştir. Bu sebeple bir sonraki deneyde katı fazdaki difüzyonu hızlandırmak için sıcaklık $750^{\circ} \mathrm{C}$ 'ye çıkarılmıştır. $750^{\circ} \mathrm{C}$ 'de yapılan deneyin XRD sonucu Şekil 7'de verilmektedir.

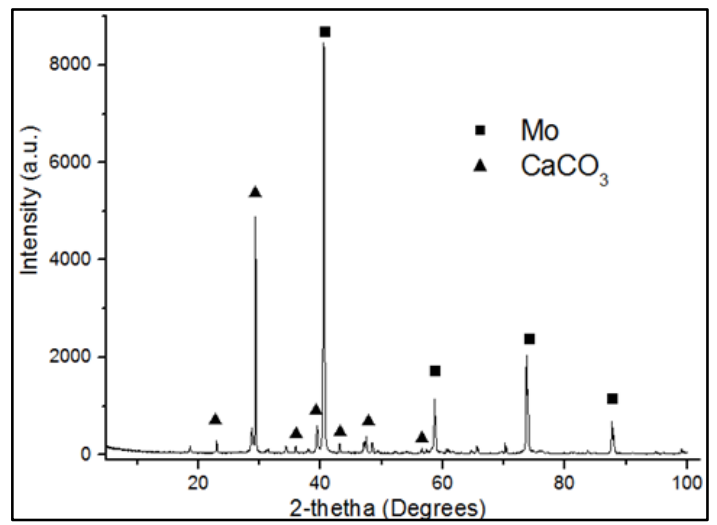

Şekil 7. $\mathrm{MoS}_{2}$ başlangıç tozu ile $750^{\circ} \mathrm{C}$ de yapılan deneyden elde edilen numunenin XRD deseni

Sekil $7^{\prime}$ 'den $750^{\circ} \mathrm{C}$ 'de Mo'nun üretilebildiği görülmüştür. Mo dışında görülen $\mathrm{CaCO}_{3}$ diğer elektrokimyasal indirgeme çalışmalarında da rastlanan bir yan üründür. 0,1 molarlık $\mathrm{HCl}$ asit çözeltisi içerisinde Mo çözünmezken $\mathrm{CaCO}_{3}$ tamamen temizlenebilmektedir. Asitten geçirilmiş numuneye ait EDS analizi sonucu Şekil 8'de verilmektedir. Buradan da görülebileceği gibi, $\mathrm{CaCO}_{3}$ 'ün tamamı temizlenebilmiştir. Numuneye ait SEM görüntüsü Şekil 9'da verilmektedir.

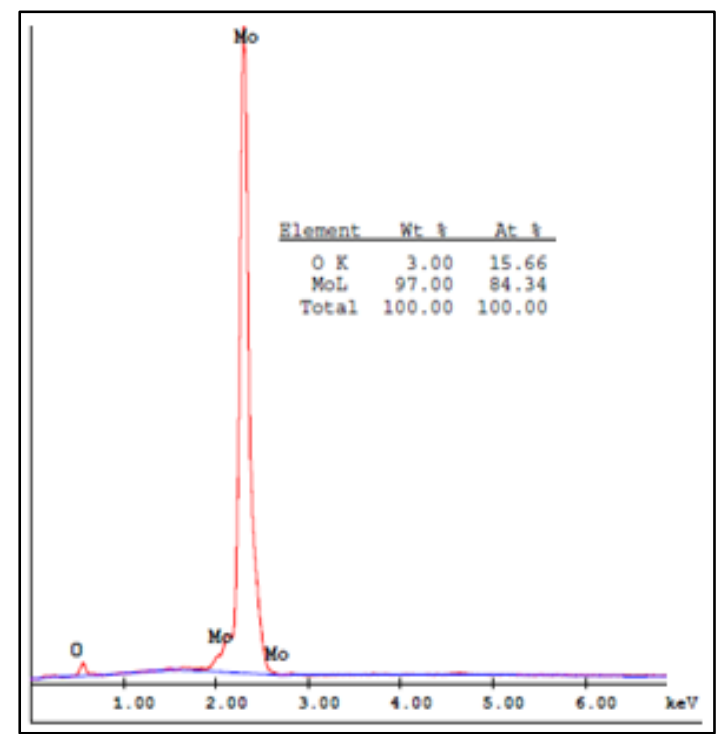

Şekil 8. $\mathrm{MoS}_{2}$ tozu ile $750^{\circ} \mathrm{C}$ 'de yapılan deney numunesinin, $0,1 \mathrm{M} \mathrm{HCl}$ temizliği sonras1 EDS analizi

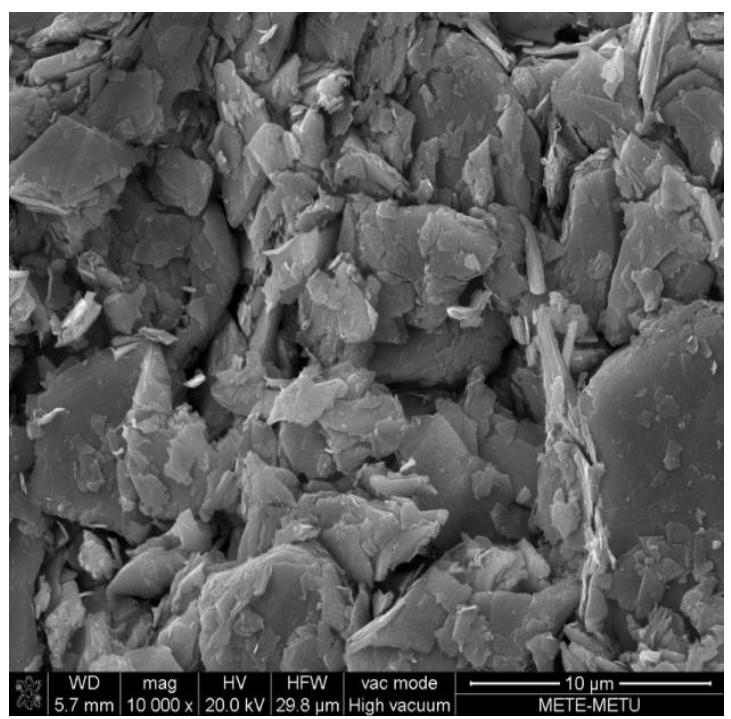

Şekil 9. $\mathrm{MoS}_{2}$ tozu ile $750^{\circ} \mathrm{C}$ 'de yapılan deney numunesinin, $0,1 \mathrm{M} \mathrm{HCl}$ temizliği sonrası SEM görüntüsü 


\section{SONUÇ}

Ülkemizde son yıllarda giderek hızlanan ARGE faaliyetlerinin, uzun vadede hammadde temininde tıkanıp kalması ihtimali bulunmaktadır. $\mathrm{Bu}$ sebeple, özellikle savunma sanayinin ihtiyaç duyduğu stratejik metallerin üretim teknolojilerine sahip olunması hayati önem taşımaktadır. Bu çalışmada, $\mathrm{CaMoO}_{4}$ ve $\mathrm{MoS}_{2}$ hammaddelerinden elektrokimyasal indirgeme yöntemiyle Mo üretimi incelenmiş̧ir.

$\mathrm{CaMoO}_{4}$ tozunun $\mathrm{CaCl}_{2}-\mathrm{NaCl}$ ötektik çözeltisi içerisinde indirgenebildiği fakat önemli bir miktarının tuz içerisinde çözündüğ̈̈ tespit edilmiștir. Çözünürlüğün önemsiz olduğu $600{ }^{\circ} \mathrm{C}$ 'de yapilan deneyde ise indirgenme sağlanamaması elektrokimyasal indirgeme işlemi için $\mathrm{CaMoO}_{4}$ 'ün uygun olmadığına işaret etmektedir.

$\mathrm{MoS}_{2}$ 'den ise Mo eldesi başarıly gerçekleştirilmiş durumdadır. Bu başlangıç malzemesi kullanılarak prosesin optimizasyonu ve son ürünün karakterizasyonuna yönelik çalışmalar yürütülmelidir.

\section{TEŞEKKÜR}

Bu çalışma TÜBİTAK 215M723, no'lu projenin sağladığı destekle tamamlanmıştır. Yazarlar TÜBİTAK'a desteklerinden ötürü teşekkür ederler.

\section{KAYNAKLAR}

1. Gupta, C.K., 1992. Extractive Metallurgy of Molybdenum. CRC Press.

2. Chen G.Z., Fray D.J., Farthing T.W., 1999. Patent No. WO1999064638 A1.

3. Chen GZ, Fray. D., Farthing T.W., 2000 Direct Electrochemical Reduction of Titanium Dioxide to Titanium in Molten Calcium Chloride. Nature, 407(6802): 361-4.

4. Gordo, E., Chen, G.Z., Fray, D.J., 2004. Toward Optimisation of Electrolytic Reduction of Solid Chromium Oxide to Chromium
Powder in Molten Chloride Salts, Electrochimica Acta, 49, 2195-2208.

5. Ergül, E., Karakaya, İ., Erdoğan, M., 2011. Electrochemical Decomposition of $\mathrm{SiO}_{2}$ Pellets to Form Silicon in Moltn Salts, Journal of Alloys and Compounds, 509, 899-903.

6. Han, W.K., Choi, J.W., Hwang, G.H., Hong, S.J., Lee, J.S., Kang, S.G., 2006. Applied Surface Science, 252, 2832.

7. Chen, G.Z., Fray, D.J., 2000. in: Progress in Molten Salt Chemistry 1, pp. 157-162.

8. Chen, G.Z., Fray, D.J., 2001. in: TMS Light Metals, New York, pp. 1147-1152.

9. Yan, X.Y., Fray, D.J., 2002. Metallurgical and Materials Transactions B, 33B, 685.

10. Abdelkader, A.M., Daher, A., El-Kashif, E., 2007. Metallurgical and Materials Transactions $\mathrm{B}, 38 \mathrm{~B}, 35$.

11. Erdoğan M., Karakaya İ., 2010. Electrochemical Reduction of Tungsten Compounds to Produce Tungsten Powder, Metall. Mater. Trans. B, 41B, 798-804.

12. Erdoğan M., Karakaya İ., 2012. On the Electrochemical Reduction Mechanism of $\mathrm{CaWO}_{4}$ to W Powder, Metall. Mater. Trans. B, 2012, 43B, 667.

13. Karakaya İ., Erdoğan M., 2007. Türk Patent Enstitüsü, TR, $07197 \mathrm{~B}$.

14. Karakaya İ., Erdoğan M., 2012. Russian Agency for Patents and Trademarks, RU 2463 387 C2, 2012.

15. Karakaya İ., Erdoğan M., 2013. Canadian Intellectual Property Office CA 2703400 A1.

16. Okyay, V., 2012. Türkiye'nin Son Gözdesi Molibden, Madencilik Türkiye, 104-110.

17.Li, G., Wang, D., Jin, X., Chen, G.Z., 2007. Electrolysis of Solid $\mathrm{MoS}_{2}$ in Molten $\mathrm{CaCl}_{2}$ for Mo Extraction without $\mathrm{CO}_{2}$ Emission, Electrochemistry Communications, 9, 1951-1957. 
